Navigation Physics 2(2) (2020)
Navigation Physics
Journal of Physics Education

\title{
EFEKTIFITAS PENERAPAN E-MODUL BERBASIS PROBLEM BASED LEARNING (PBL) TERHADAP KETERAMPILAN PROSES SAINS SISWA SMA
}

\author{
Sri Mayanty ${ }^{1}$, I Made Astra², Cecep E. Rustana ${ }^{2}$ \\ ${ }^{1 *}$ Universitas Indraprasta PGRI \\ ${ }^{2}$ Universitas Negeri Jakarta \\ *Email: mayanty_sri@yahoo.com
}

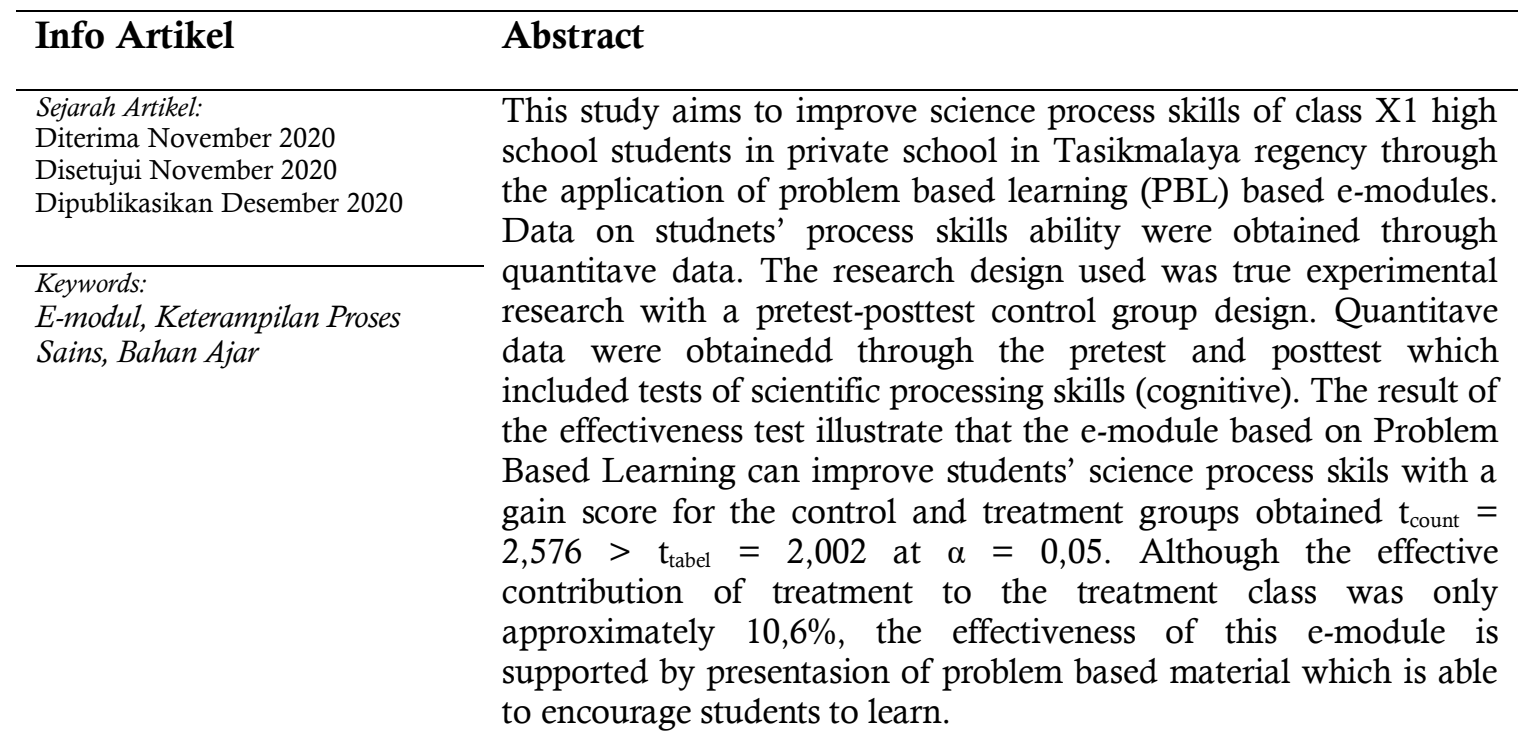

How to Cite: Mayanty, S., Astra, I. M., \& Rustana, C. E. (2020). Efektifitas Penerapan E-Modul Berbasis Problem Based Learning (PBL) Terhadap Keterampilan Proses Sains Siswa SMA. Navigation Physics, 2 (2): 98-105.

\section{PENDAHULUAN}

Mata pelajaran fisika merupakan salah satu bagian dari Ilmu Pengetahuan Alam (IPA). Mata pelajaran IPA bertujuan mengembangkan pengetahuan dan konsep IPA yang berkaitan dengan kehidupan sehari-hari, mengembangkan rasa ingin tahu, dan tentunya dapat mengembangkan keterampilan proses siswa seperti dalam memecahkan suatu permasalahan yang berkaitan dengan aplikasi dari konsep fisika tersebut. Pada pembelajaran sains ini banyak dikenalkan keterampilan berpikir yang berkaitan dengan seluruh aktivitas sains.

Proses belajar yang ditandai dengan adanya perubahan pada diri seorang diartikan dengan adanya perubahan hasil proses belajar yang ditujukan dalam berbagai bentuk seperti berubah pengetahuannya, pemahamannya, sikap dan tingkah lakunya, keterampilannya, kecakapannya dan kemampuannya (Musfiqon, 
2012). Sedangkan menurut (Dewi, 2009) Keterampilan-keterampilan tersebut merupakan bagian yang membentuk landasan untuk menerapkan metode-metode ilmiah, ketika siswa merancang dan mengadakan sebuah eksperimen, maka siswa tersebut akan menggunakan kombinasi dari keterampilan-keterampilan proses sains yang dimilikinya. Keterampilan Mengamati, keterampilan mengukur, keterampilan menyimpulkan, keterampilan memprediksi dan keterampilan mengkomunikasikan itu merupakan kemampuan proses sains dasar yang harus dimiliki siswa.

Namun berdasarkan hasil observasi di lapangan masih ditemukan beberapa kendala yang berkaitan dengan bahan ajar dan keterampilan proses sains siswa. Masalah yang ditemukan peneliti dalam observasi awal antara lain dari aspek keterampilan proses sains kurang menuntun siswa untuk mengamati suatu fenomena, siswa masih belum mampu menggunakan alat ukur dengan benar, masih kurangnya kemampuan siswa untuk memprediksi suatu fenomena, dan siswa masih belum terbiasa untuk mengkomunikasikan hasil dari pengamatannya tersebut. Sehingga diperlukan suatu bahan ajar yang interaktif bagi siswa. Menurut (Prastowo, 2014) bahan ajar yang interaktif yaitu kombinasi dari dua atau lebih media (audia, teks, grafik, gambar, animasi dan video) yang kemudian dimanipulasi oleh penggunanya atau diberi perlakuan untuk mengendalikan suatu perintah. Sseiring dengan perkembangan teknologi yang semakin pesat, teknologi juga berpengaruh pada dunia pendidikan, termasuk pemanfaatan teknologi untuk bahan ajar dalam pembelajaran yang saat ini semakin berkembang dan lebih efisien untuk sekarang.

Pengembangan bahan ajar dengan menggunakan teknologi komputer sangat diperlukan. Dengan adanya pengembangan ini siswa bisa melakukan belajar dengan mandiri, kapanpun, dan dimana saja. Hal ini sejalan dengan konsep modul yang dikemukakan (Darmiatun, 2013) bahwa modul diartikan sebagai materi pelajaran yang disusun dan disajikan secara tertulis sehingga pembacanya bisa dapat menyerap sendiri materi tersebut dengan kata lain pembacanya dapat belajar mandiri. Berkaitan dengan perkembangan teknologi di abad 21 maka peneliti menggabungkan pengembangan media pembelajaran dan teknologi komputer ini sehingga akan menghasilkan e-modul (modul berbasis elektronik).

Selain itu juga pada pembelajaran sains dibutuhkan suatu proses yang dapat merangsang siswa untuk belajar melalui berbagai permasalahan nyata dalam kehidupan sehari-hari. Permasalahan yang dikaji hendaknya permasalahan konstektual yang ditemukan oleh siswa dalam kehidupan sehari-hari.hal ini sesuai dengan pembelajaran model PBL. Model PBL memungkinkan siswa untuk terlibat dalam mempelajari halhal, antara lain: permasalahan dunia nyata, keterampilan berpikir tingkat tinggi, keterampilan menyelesaikan permasalahan, belajar antardisiplin ilmu, belajar mandiri, belajar menggali informasi, belajar bekerja sama dan belajar keterampilan berkomunikasi (Sani, 2015).

Dalam rangka menunjang keterampilan tersebut diperlukan suatu media yang dapat memadukan antara model Problem Based Learning dengan bahan ajar berbasis mandiri berupa e-modul tentunya akan menghasilkan produk bahan ajar yang kreatif dan inovatif. Adanya saling keterkaitan antara bahan ajar elektronik (e-modul) dengan pembelajaran model Problem Based Learning akan memberikan kesempatan siswa untuk belajar mandiri serta mengembangkan keterampilan sains yang dimiliki siswa. Dikarenakan proses belajar dalam Problem Based Learning memberikan kesempatan siswa untuk menemukan konsep-konsep dalam pembelajaran dengan tahapan yang berawal dari suatu masalah mengorganisasi siswa untuk berorganisasi, membantu penyelidikan, mengembangkan dan mempresentasikan hasil serta menganalisis dan mengevaluasi proses pemecahan masalah. Sedangkan e-modul membantu dan membimbing siswa secara bertahap untuk menemukan konsep-konsep sesuai dengan tahapan-tahapan pada model Problem Based Learning dengan mengikuti era digital.

Pembelajaran dengan menggunakan bahan ajar ini diarahkan untuk meningkatkan keterampilan proses sains. Dalam meningkatkan keterampilan proses sains ini perlu penggiring yang dapat mengantarkan siswa terhadap kegiatan-kegiatan yang berkaitan dengan keterampilan proses sains. Kegiatan e-modul ini merupakan salah satu bahan ajar yang menuntut kemandirian siswa untuk menemukan suatu konsep. Hal ini didukung berdasarkan hasil penelitian Febrianti dkk (2017) yang menunjukan bahwa e-modul fisika yang dikembangkan layak digunakan sebagai bahan belajar mandiri untuk siswa. Selain itu juga berdasarkan penelitian Sumiati dkk (2018) menunjukan bahwa modul fisika yang dikembangkan mampu meningkatkan keterampilan proses sains siswa terlihat dengan gain score sebesar 0,4 dengan kategori sedang.

Dengan adanya e-modul berbasis Problem Based Learning, siswa dapat meningkatkan kemampuan sains siswa dikarenakan bahan ajar yang disajikan dapat membantu, membimbing siswa dalam menemukan konsep yang berawal dari permasalahan. Selain itu juga dengan tampilan e-modul ini akan mempermudahkan siswa untuk emningkatkan keterampilan proses sains siswa. Oleh karena itu penelitian berkaitan dengan efektifitas mengenai e-modul berbasis Problem Based Learning untuk meningkatkan keterampilan sains siswa. 


\section{METODE PENELITIAN}

Jenis penelitian ini adalah true experimental dengan Pretest-Posttest Control Group Design. Penelitian ini menggunakan kelas pembanding yaitu adanya kelas kontrol dan kelas perlakuan. Kelompok perlakuan adalah siswa yang belajar dengan menggunakan bahan ajar berupa e-modul fisika berbasis Problem Based Learning (PBL), dan kelompok kontrol yang tidak menggunakan bahan ajar berupa e-modul fisika berbasis Problem Based Learning (PBL). Setiap kelompok diberikan pre test untuk mengetahui pemahaman awal siswa sebelum diberikan e-modul berbasis Problem Based Learning (PBL). Setelah diberikan tes awal, slanjutnya kelas perlakuan akan mendapat pembelajaran dengan menggunakan e-modul sedangkan untuk kelas kontrol dengan metode pembelajaran yang biasa menggunakan buku sumber yang ada. Selanjutnya siswa akan diberi tes akhir (posttest) untuk mengetahui sejauh mana pengaruh pembelajaran e-modul menggunakan e-modul berbasis Problem Based Learning (PBL) terhadap keterampilan proses siswa. Secara sederhana, desain penelitian yang akan digunakan seperti Gambar 1. Berikut ini.

\begin{tabular}{lll}
$\mathrm{O}$ & $\mathrm{X}$ & $\mathrm{O}$ \\
\cline { 1 - 1 } $\mathrm{O}$ & $\mathrm{C}$ & $\mathrm{O}$
\end{tabular}

Keterangan :

X: Perlakuan yaitu menggunakan bahan ajar e-modul

C: Kontrol, tanpa menggunakan bahan ajar e-modul

O: Observasi Pre Test-Post Test

Efektifitas media e-modul berbasis Problem Based Learning (PBL) dianalisis mengggunakan persamaan Ngain dan diuji dengan uji $\mathrm{T}$. Untuk rata-rata gain yang dinormalisasi $(<\mathrm{g}>)$ dirumuskan seperti persamaan 1 berikut ini:

$$
g>=\frac{\langle\text { Spost }>-<\text { Spre }>}{100 \%-<\text { Spre }>}
$$

Data uji efektivitas adalah hasil pretest dan post test keterampilan proses sains pada materi suhu dan kalor yang menggunakan e-modul sebagai kelompok perlakuan dan yang tidak menggunakan e-modul sebagai kelompok kontrol. Hasil tes tersebut diuji perbedaannya dengan menggunakan uji t independen pada taraf signifikansi 0,05 .

Sebelum dianalisis dilakukan pengujian prasyarat yaitu dengan menggunakan uji normalitas dan homogenitas. Uji normalitas menggunakan uji Kormogorov-sminov pada $\alpha=0,05$ dan uji homogenitas menggunakan uji variansi. Analisis uji beda pada taraf signifikansi 0,05 yang dilakukan sebanyak 4 kali, yaitu: (1) uji t pretest dan post test kelompok perlakuan, (2) uji t pretest dan post test kelompok kontrol, (3) uji t post test kelompok perlakuan dan post test kelompok kontrol dan (4) uji t gain skor kelompok perlakuan dan gain skor kelompok kontrol.

\section{HASIL DAN PEMBAHASAN}

Menurut (Rusmono, 2012) model Pembelajaran Problem Based Learning (PBL) memiliki ciri-ciri meliputi menggunakan permasalahan dalam dunia nyata, pembelajaran dipusatkan pada penyelesaian masalah, tujuan pembelajaran ditentukan oleh siswa, serta guru berperan sebagai fasilitator. Sehingga Pada materi e-modul ini dibagi menjadi 3 sub bab yaitu suhu dan pengukuran, zat dan kalor serta perpindahan kalor. Setiap materi disajikan menurut tahapan Problem Based Learning (PBL) yaitu meliputi: permasalahan, tugas belajar, penyelidikan, pengembangan hasil, dan analisis dan evaluasi pemecahan masalah. Materi ajar yang disajikan dilengkapi dengan video, animasi, simulasi dan v-lab yang menunjang materi. E-modul seperti itu dapat membuat siswa belajar secara visual, audio bahkan interaktif dengan penyajian tersebut. Sehingga dengan emodul yang dikembangkan ini dapat memberikan motivasi dan semangat kepada siswa untuk belajar sesuai 
dengan pernyataan (Widodo, 2008). Dalam pengembangan e-modul berbasis Problem Based Learning ini dilengkapi dengan video, animasi, simuasi dan virtual lab sehingga dapat menggugah siswa untuk belajar.

E-modul ini dilengkapi dengan latihan soal yang terdiri dari 5 butir soal. Setelah diberi latihan soal, terdapat soal tes formatif. Soal tes formatif ini disajikan tiap sub bab dengan tujuan dapat mengukur sejauh mana pemahaman siswa dan pengembangan keterampilan proses sains siswa pada setiap sub bab. Serta untuk tes sumatifnya hasil pengerjain siswa tersimpan ke dalam format pdf. Sehingga kita dapat melihat siswa belum mengerti dan mengerti di bagian mananya.Pertanyaan yang disajikan menuntut siswa untuk memahami konsep yang terdapat pada tiap sub bab e-modul tersebut. Dan di bagian terakhir terdapat tes kognitif keterampilan proses sains. Disajikan pula daftar pustaka untuk memberikan referensi yang digunakan dalam pengembangan e-modul ini.

Pengujian efektivitas bahan ajar dilakukan dengan metode eksperimen. Uji keefektifan bertujuan untuk melihat apakah bahan ajar berupa e-modul fisika berbasis Problem Based Learning (PBL) yang dikembangkan layak digunakan sebagai bahan ajar bagi siswa untuk meningkatkan proses keterampilan sains. Pelaksanaan uji efektivitas dilakukan pada siswa SMA kelas XI, yang masing-masing dibagi menjadi kelompok perlakuan dan kelompok kontrol.

Kelompok perlakuan adalah siswa yang belajar dengan menggunakan bahan ajar berupa e-modul fisika berbasis Problem Based Learning (PBL), dan kelompok kontrol yang tidak menggunakan bahan ajar berupa emodul fisika berbasis Problem Based Learning (PBL). Setiap kelompok diberikan pre tes untuk mengetahui pemahaman awal siswa dan kegiatan selanjutnya masing-masing kelompok diberikan waktu untuk mempelajari materi suhu dan kalor selama 2 minggu. Pada akhir kegiatan, kedua kelompok diberikan post test untuk mengetahui peningkatan keterampilan proses sains dasar siswa pada materi suhu dan kalor.

Berdasarkan hasil uji efektivitas menunjukan bahwa post test dan gain skor pada kelompok siswa yang belajar menggunakan bahan ajar berupa e-modul fisika berbasis Problem Based Learning (PBL) lebih tinggi dibandingkan dengan kelompok siswa yang tidak bahan ajar berupa e-modul fisika berbasis Problem Based Learning (PBL).Untuk lebih menguatkan pernyataan tersebut dilakukan analisis statistik, untuk melihat perbedaan antara kedua kelompok tersebut. Secara rinci hasil uji efektifitas dapat dilihat pada tabel 4.1 berikut:

Tabel 1. Deskripsi Data Skor Pre Tes dan Post Test Dari Kelompok Perlakuan dan Kelompok Kontrol Pada Uji Efektifitas E-modul

\begin{tabular}{llll}
\hline \multirow{2}{*}{ Keterampilan Proses Sains } & \multicolumn{2}{c}{ Kelompok } \\
\cline { 2 - 4 } Siswa & \multicolumn{1}{c}{ Perlakuan } & \multicolumn{1}{c}{ Kontrol } \\
\hline Skor PreTest & Jumlah & 203 & 217 \\
& Rerata & 6,77 & 7,23 \\
& Modus & 8 & 8 \\
& Median & 7 & 8 \\
& Standar Deviasi & 3,36 & 2,73 \\
Skor Post Test & Varians & 11.29 & 5,63 \\
& Jumlah & 559 & 506 \\
& Rerata & 18,63 & 16,87 \\
& Modus & 19 & 18 \\
& Median & 19 & 17 \\
& Standar Deviasi & 2,25 & 2,42 \\
Gain Skor & Varians & 5,07 & 5,84 \\
& Jumlah & 356 & 289 \\
& Rerata & 11,9 & 9,63 \\
& Modus & 15 & 9 dan 10 \\
& Median & 12 & 9,5 \\
& Standar Deviasi & 3,09 & 3,49 \\
& Varians & 9,57 & 12,24 \\
\hline
\end{tabular}

Analisis statistik yang digunakan untuk melihat perbedaan hasil pre tes dan post test pada kedua kelompok menggunakan t-test. Sebagai prasyarat t-test setiap data yang diperoleh dilakukan uji normalitas dan 
homogenitas. Hasil analisis uji beda (t-test) dilakukan untuk membedakan rata-rata variabel dua kelompok. Uji hipotesis perbedaan parameter antara dua kelompok dapat digunakan statistik uji t. Uji beda (t-test) independen dilakukan sebanyak empat kali dan didapatkan hasil analisis sebagai berikut:

\section{Uji t Skor Post Test Kelompok Perlakuan dan Kelompok Kontrol Keterampilan Proses Sains Siswa}

Analisis uji t terhadap skor post test kelompok perlakuan dan kelompok kontrol bertujuan untuk mengetahui ada tidaknya perbedaan yang signifikan nilai post test pada kelompok perlakuan dan kontrol. Hasil uji t terhadap skor post test dapat dilihat pada Tabel 2 berikut:

Tabel 2. Hasil Analisis Uji Beda Post Test Pada Kelompok Perlakuan dan Kontrol Keterampilan Proses Siswa

\begin{tabular}{|c|c|c|c|c|c|}
\hline \multirow[t]{2}{*}{ Kelompok Uji } & \multirow[t]{2}{*}{ Rerata } & \multicolumn{3}{|c|}{ Statistik Uji } & \multirow[t]{2}{*}{ Keterangan } \\
\hline & & Dk & $t_{\text {hitung }}$ & $t_{\text {tabel }}(0,05)$ & \\
\hline Post Test Perlakuan & 18,663 & 58 & 2,879 & 2.002 & berbeda \\
\hline Post Test Kontrol & 16,867 & & & & \\
\hline
\end{tabular}

Berdasarkan Tabel rata-rata skor post test kelompok perlakuan sebesar 18,663 dan rata-rata skor post test kelompok kontrol sebesar 16,867. Rerata skor post test kelompok perlakuan dan kelompok kontrol dapat dilihat pada Gambar 2. berikut:

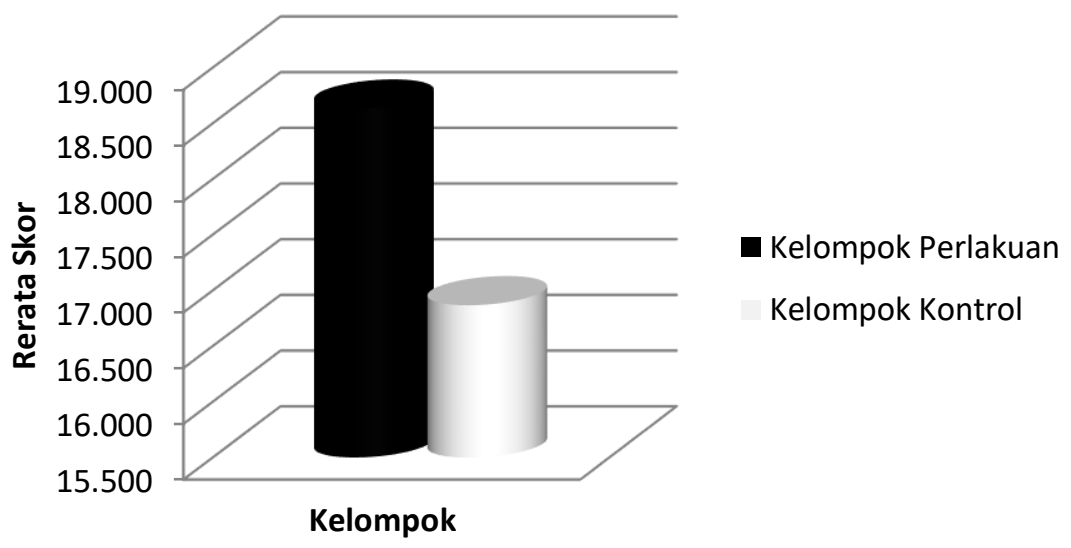

Gambar 2. Rerata Skor Post test Kelompok Perlakuan dan Kelompok Kontrol

Hasil analisis uji t pada skor post test kelompok perlakuan dan kelompok kontrol diperoleh $\mathrm{t}_{\text {hitung }}=2,879>$ $\mathrm{t}_{\text {tabel }}=2,002$ pada $\alpha=0,05$. Dengan demikian yang berarti terdapat perbedaan skor post test keterampilan proses sains siswa pada kelompok perlakuan yang diberikan e-modul berbasis Problem Based Learning (PBL) dengan kelompok kontrol yang tidak diberikan e-modul berbasis Problem Based Learning (PBL). Artinya keterampilan proses sains siswa pada kelompok yang menggunakan e-modul berbasis Problem Based Learning (PBL) dan tidak menggunakannya menunjukan perbedaan yang nyata.

Pada proses pembelajaran kelompok yang menggunakan e-modul berbasis PBL merasa terbantu dengan adanya gambar, video, animasi, simulasi dan v-lab pada saat mempelajari konsep yang berkaitan dengan suhu dan kalor. Video yang disajikan di pendahuluan memberikan semangat kepada siswa untuk memulai pembelajaran. Animasi dan simulasi membuat siswa interaktif untuk memperoleh konsep yang dapat siswa peroleh sendiri dari sajian e-modul tersebut. Sehingga dengan sajian e-modul seperti ini dapat memberikan semngat dan motivasi siswa untuk belajar selain itu juga dapat mengembangkan kemampuan yang dimiliki siswa. Hal ini sesuai dengan pernyataan (Susilana, 2009) bahwa e-modul merupakan bahan ajar yang interaktif, dimana siswa tidak hanya membaca teks tetapi juga melihat animasi tentang sebuah proses menyerupai proses yang sebenarnya sehingga mempermudah pemahaman siswa 


\section{Uji t Pada Gain Skor Kelompok Perlakuan dan Kelompok Kontrol Keterampilan Proses Sains Siswa}

Uji t gain skor kelompok perlakuan dan kelompok kontrol bertujuan untuk mengetahui ada tidaknya perbedaan selisih post test-pretest yang signifikan antara kedua kelompok tersebut. Adapun hasil uji t gain skor kelompok perlakuan dan kontrol berdasarkan perhitungan spss adalah seperti tabel 3. Berikut ini:

Tabel 3. Hasil Analisis Uji Beda Gain Skor Kelompok Perlakuan dan Kontrol Keterampilan Proses Sains Siswa Berdasarkan SPSS

\begin{tabular}{|c|c|c|c|c|c|c|c|c|c|}
\hline & \multicolumn{2}{|c|}{$\begin{array}{l}\text { Levene's } \\
\text { Test For } \\
\text { Equality of } \\
\text { Variances }\end{array}$} & \multicolumn{7}{|c|}{ t-test for equality of Means } \\
\hline & \multirow[t]{2}{*}{$\mathrm{F}$} & \multirow[t]{2}{*}{ Sig. } & \multirow[t]{2}{*}{$\mathrm{t}$} & \multirow[t]{2}{*}{$\mathrm{df}$} & \multirow[t]{2}{*}{$\begin{array}{c}\text { Sig } \\
\text { (2-taled) }\end{array}$} & \multirow[t]{2}{*}{$\begin{array}{c}\text { Mean } \\
\text { difference }\end{array}$} & \multirow[t]{2}{*}{ Std eror } & \multicolumn{2}{|c|}{$\begin{array}{c}95 \% \\
\text { Confidence } \\
\text { interval }\end{array}$} \\
\hline & & & & & & & & lower & Upper \\
\hline $\begin{array}{ll}\text { GAIN Equal } \\
\text { variance } \\
\text { assumed }\end{array}$ & 210 & .649 & 2.619 & 58 & .011 & 2.233 & .853 & .527 & 3.940 \\
\hline $\begin{array}{l}\text { Equal } \\
\text { varianced not } \\
\text { assumed }\end{array}$ & & & 2.619 & 57.142 . & .011 & 2.233 & .853 & .526 & 3.941 \\
\hline
\end{tabular}

Dari data tersebut diperoleh nilai $t=2,619$. Selain itu juga apabila dibandingkan dengan hasil uji $t$ gain skor kelompok perlakuan dan kontrol dapat dilihat pada Tabel 4.

Tabel 4. Hasil Analisis Uji Beda Gain Skor Kelompok Perlakuan dan Kontrol Keterampilan Proses Sains Siswa

\begin{tabular}{|c|c|c|c|c|c|}
\hline \multirow[t]{2}{*}{ Kelompok Uji } & \multirow[t]{2}{*}{ Rerata } & \multicolumn{3}{|c|}{ Statistik Uji } & \multirow[t]{2}{*}{ Keterangan } \\
\hline & & $\mathrm{Dk}$ & $t_{\text {hitung }}$ & $t_{\text {tabel }}(0,05)$ & \\
\hline Gain Skor Perlakuan & 11,867 & 58 & 2,576 & 2.002 & Berbeda \\
\hline Gain Skor Kontrol & 9,633 & & & & \\
\hline
\end{tabular}

Berdasarkan Tabel 4.31 rata-rata gain skor post test kelompok perlakuan sebesar 11,867 dan rata-rata gain skor post test kelompok kontrol sebesar 9,633. Rerata gain skor kelompok perlakuan lebih tinggi daripada rerata gain skor kelompok kontrol. Rerata gain skor kelompok perlakuan dan kelompok kontrol dapat dilihat pada Gambar 4.14 berikut:

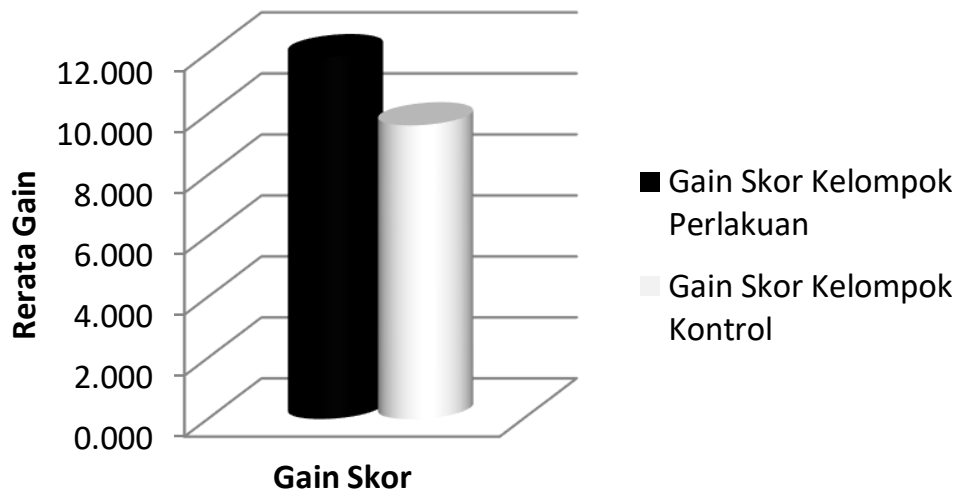


Gambar 3. Gain Skor Keterampilan Proses Sains Siswa

Berdasarkan hasil analisis uji t berdasarkan pengolahan pada spss diperoleh $t=2,619$. Sedangkan hasil hitung pada gain skor kelompok perlakuan dan kelompok kontrol diperoleh $t_{\text {hitung }}=2,576>t_{\text {tabel }}=2,002$ pada $\alpha=0,05$. Dengan demikian tolak Ho yang berarti terdapat perbedaan gain skor keterampilan proses sains siswa antara kelompok perlakuan dengan kelompok kontrol, artinya pada kelompok siswa yang menggunakan e-modul berbasis Problem Based Learning (PBL) menunjukan peningkatan keterampilan proses sains lebih tinggi dibandingkan dengan kelompok kontrol yang tidak menggunakan e-modul berbasis Problem Based Learning (PBL). Sehingga berdasarkan data tersebut dapat diperoleh berapa persen sumbangan perlakuan yang diberikan dalam meningkatkan skor pada kelompok eksperimen. Hasilnya dapat dilihat pada tabel di bawah ini.

Tabel 5. Omega Squared untuk Uji t dua sampel

\begin{tabular}{|c|c|c|c|c|c|c|c|c|c|}
\hline Model & $\mathrm{R}$ & $\begin{array}{l}\mathrm{R} \\
\text { square }\end{array}$ & $\begin{array}{l}\text { Adjusted } \\
\text { Square }\end{array}$ & $\mathrm{R}$ & $\begin{array}{l}\text { Std. Error of } \\
\text { the Estimate }\end{array}$ & & & & \\
\hline 1 & & & & & & $.325^{\mathrm{a}}$ & .106 & .090 & 3.302 \\
\hline
\end{tabular}

Berdasarkan tabel 4.31 nilai $\mathrm{R}$ square yaitu sebesar 0,106 atau 10,6\% sehingga dapat dikatakan bahwa besarnya pengaruh e-modul terhadap kemampuan keterampilan proses adalah 10,6\%. Berdasarkan hasil perhitungan uji t antara kelompok perlakuan dengan kontrol, menggambarkan bahwa keterampilan proses sains siswa yang belajar dengan menggunakan e-modul berbasis Problem Based Learning (PBL) berbeda dengan yang tidak menggunakan e-modul. E-modul berbasis Problem Based Learniing (PBL) ini didesain dengan menggunakan tahapan Problem Based Learniing (PBL), dimana pembahasan materi berawal dari permasalahan di kehidupan sehari-hari. Selain itu juga e-modul ini dapat memvisualisasikan materi dengan menarik, sehingga materi yang abstrak bisa dijabarkan kepada siswa. Hal ini memudahkan siswa memahami konsep dan mampu mengembangkan keterampilan proses sains sehingga terlihat dengan gain score kelompok perlakuan yang lebih tinggi dibandingkan dengan kelompok kontrol.

Dari hasil tersebut sesuai dengan pernyataan Hamzah \& Muhammad (2012) jika seluruh kegiatan pembelajaran dalam proses belajar mengajar itu dalam gerak dan tindakan untuk menemukan dan mengembangkan fakta dan konsep serta menumbuhkan dan mengetahui nilai, maka peristiwa tersebut dinamakan keterampilan proses. Keterampilan dasar yang perlu dikembangkan meliputi mengamati (observasi), menghitung, mengukur, mengklasifikasi, menarik hubungan antar variabel, merumuskan hipotesis, merencanakan penelitian/melakukan eksperimen, mengendalikan variabel, menafsirkan data, membuat kesimpulan sementara, membuat prediksi, menerapkan dan mengkomunikasikan.

\section{PENUTUP}

Simpulan E-modul berbasis Problem Based Learning (PBL) pada pokok bahasan suhu dan kalor efektif untuk mampu meningkatkan keterampilan proses sains siswa. Hal ini dapat dilihat dari uji efektifitas e-modul berbasis Problem Based Learning (PBL) untuk nilai gain skor untuk kelompok kontrol dan perlakuan diperoleh $\mathrm{t}_{\text {hitung }}=2,576>\mathrm{t}_{\text {tabel }}=2,002$ pada $\alpha=0,05$. Dan saran untuk Penelitian pengembangan e-modul serupa mungkin sebaiknya menggunakan sampel dengan jumlah besar agar e-modul tersebut dapat secara umum dipakai secara efektif oleh siswa dimana pun juga. 
Sri Mayanty, et all / Navigation Physics 2 (2) (2020)

Efektifitas Penerapan E-modul Berbasis Problem

\section{DAFTAR PUSTAKA}

Darmiatun, S. (2013). Menyusun Modul Bahan Ajar untuk Persiapan Guru dalam Mengajar. Yogyakarta: Gava Media.

Dewi, S. (2009). Keterampilan Proses Sains. Bogor: CV Regina.

Febrianti, K. V., Bakri, F., \& Nasbey, H. (2017). Pengembangan Modul Digital Fisika berbasis Discovery Learning pada Pokok Bahasan Kinematika Gerak Lurus. WaPFi (Wahana Pendidikan Fisika), 2(2), $18-26$.

Hamzah, B. U., \& Mohamad, N. (2012). Belajar dengan pendekatan PAILKEM. Jakarta: Bumi Aksara.

Musfiqon. (2012). Pengembangan Media dan Sumber Belajar. Jakarta: PT. Prestasi Pustakarya.

Prastowo, A. (2014). Panduan Kreatif Membuat Bahan Ajar. Yogyakarta: Diva Press.

Rusmono. (2012). Strategi Pembelajaran dengan Problem Based Learning itu Perlu. Bogor: Ghalia Indonesia.

Sani. (2015). Pembelajaran Saintifik untuk Implementasi Kurikulum 2013. Jakarta: Bumi Aksara.

Sumiati, E., Septian, D., \& Faizah, F. (2018). Pengembangan modul fisika berbasis Scientific Approach untuk meningkatkan Keterampilan Proses Sains siswa. Jurnal Pendidikan Fisika dan Keilmuan (JPFK), $4(2), 75-88$.

Susilana, R. (2009). Media Pembelajaran Hakikat Pengembangan, Pemanfaatan dan Penilaian. Bandung: CV Wacana Prima.

Widodo, C. S. (2008). Panduan Menyusun Bahan Ajar Berbasis Kompetensi. Jakarta: Gramedia. 